\title{
Challenges and Coping Strategies Adopted by Postgraduate Students of Agricultural Education in Thesis Writing in Nigerian Universities
}

\author{
Vincent C. Asogwa', Adoo D. Wombo' ${ }^{1}$, Charles U. Ugwuoke ${ }^{2}$ \\ ${ }^{1}$ Department of Agricultural Education, University of Agriculture, Makurdi, Nigeria \\ ${ }^{2}$ Department of Vocational Teacher Education, University of Nigeria, Nsukka, Nigeria \\ Email: asovinchidi@yahoo.com
}

Received 23 June 2014; revised 20 July 2014; accepted 10 August 2014

Copyright (C) 2014 by authors and Scientific Research Publishing Inc.

This work is licensed under the Creative Commons Attribution International License (CC BY). http://creativecommons.org/licenses/by/4.0/

(c) (i) Open Access

\begin{abstract}
The study investigated challenges encountered and coping strategies adopted by postgraduate students of agricultural education in writing thesis in Nigerian universities. Two research questions and two hypotheses guided the study. The study was conducted in Nigerian universities offering post-graduate programme in agricultural education. The population for the study was 118 made up of 14 postgraduate diploma, 66 masters and 38 doctoral students writing thesis in agricultural education. The entire population was involved in the study. An instrument tilted: Challenges and Coping Strategies Questionnaire (CCSQ) was used for data collection. Three experts validated the questionnaire. Cronbach alpha reliability method was used to determine the internal consistency of the questionnaire. A reliability coefficient of 0.85 was obtained. A total of 97 copies of the questionnaire were returned representing 93 percent return rate. Data collected for the study were analyzed using mean and standard deviation to answer the research questions while Analysis of Variance was used to test hypothesis of no significant difference at $P \leq 0.05$ level of significance. The statistical package for social sciences (SPSS) was the tool employed to analyze the data collected. It was found out that 28 challenges were encountered by postgraduate students of agricultural education in thesis writing while 15 coping strategies were adopted by postgraduate students of agricultural education in thesis writing. The recommendations were that postgraduate students of agricultural education who have abandoned their thesis writing should adopt the identified coping strategies to complete their programme among others.
\end{abstract}

\section{Keywords}

Challenges, Coping Strategies, Postgraduate Students, Agricultural Education, Thesis Writing 


\section{Introduction}

The importance of agriculture to mankind justified the need for equipping younger generation with knowledge and skills in agriculture through agricultural education. Reference [1] defined agricultural education as the scientific study of the principles and methods of teaching and learning as they pertained to agriculture. It refers to those activities directed at the preparation of teachers of vocational agriculture. Reference [2] explained that agricultural education was the teaching of agriculture, natural resources, and land management through hands on experience and guidance to prepare students for entry level jobs, further education and advanced agricultural jobs. Reference [3] described agricultural education as a programme designed for preparing or equipping learners with knowledge, skills and attitude in teaching and technical areas of agriculture to enable them impart the same to students in schools and colleges. Therefore, agricultural education is a planned series of activities for equipping students with knowledge, skills and attitude in pedagogy and agriculture for effective teaching in primary and secondary schools after graduation. Reference [4] observed that salient characteristics of agricultural education include:

1) Agricultural education applies technologies and theories from the biological and physical sciences, psychology, and sociology;

2) The foundation of agricultural education is formed from Agriculture and education;

3) Agriculture education bridges and focuses on the principles and methods of teaching and learning about agricultural science and technology;

4) The general processes used in agricultural education to apply teaching and learning are: curriculum planning, delivery methodologies and program evaluation; and

5) Application settings for agricultural education include universities, secondary schools, vocational schools, extension, industry, and agencies.

The observation of the authors above was buttressed by the statement of [2] that agricultural education was taught at the elementary, middle school, secondary, adult and post secondary levels such as universities. In Nigerian universities, agricultural education is offered at undergraduate and postgraduate education level.

Postgraduate education, in the submission of [5] involves learning and studying for degrees, professional or academic certificates, or other qualifications for which a first or Bachelor's degree generally is required; and it is normally considered to be part of higher education. The students in this level of education are usually referred to as postgraduate students. Reference [6] described post graduate students as individuals who are studying for a degree beyond that of their bachelor degree to obtain postgraduate diploma, masters or doctorate degree. Reference [7] asserted that postgraduate students were learners who continued to study for an advanced degree after earning a bachelor's degree or other first degree. They are students who have obtained degrees from a university or other tertiary institutions and are engaged in studies for a more advanced qualification. In the context of this study, postgraduate students are individuals who have first degree in agricultural education programme or in other related degree courses in agriculture and are studying for postgraduate diploma, masters or doctorate (Ph.D) degree in agricultural education. In Nigeria, postgraduate students in agricultural education take some course works and thesis writing with a unit credit load ranging from 4 to 12 depending on the degree in view.

Thesis is an aspect of postgraduate education which students must pass satisfactorily to merit the award of postgraduate degree. Reference [8] defined thesis as a long essay or dissertation involving personal research, written by a candidate for a university degree. It is a dissertation advancing an original point of view as a result of research, especially as a requirement for an academic degree. Reference [9] referred to thesis as a lengthy academic paper or dissertation based on original research, especially as work geared towards an academic degree. With reference to this study, thesis is an academic treatise written by a postgraduate student of agricultural education based on original research for the award of masters or doctorate degree. The process of creating thesis by a postgraduate student is known as thesis writing.

In the explanation of [10], thesis writing is the creation of a research project or dissertation that generally involves an empirical investigation of specific question(s) within the field of one's study. The common theme to all thesis writing is to expand the students' understanding within the field of study and be equipped with the knowledge and skills in conducting research, teaching, textbook and paper writing. The author mentioned further that the processes involved in thesis writing include:

1) creating the prospectus/a short document (thesis proposal) through the literature;

2) thesis proposal meeting with the thesis committee; 
3) field work for data collection;

4) data analysis and result reporting;

5) thesis defense meeting with the thesis committee;

6) thesis synopsis; and

7) thesis oral.

However, the author noted that thesis writing varied substantially with institutions, thesis committee and supervisors, thereby making it difficult to describe procedures that applied to all students. Reference [11] postulated that students found thesis writing as the most challenging part of postgraduate studies. This is in line with the observation of the researchers that the highest challenges encountered by postgraduate students are in thesis writing.

Challenge, in the statement of [7], means a task or situation that tests someone's ability. It also refers to difficulty in a job or career which tests one's ability or resources in a demanding but stimulating undertaking. In this study, challenges are those difficult situations which postgraduate students of agricultural education encounter on the course of their thesis writing. According to [12], the challenges faced by students in research range from inability to select a researchable topic, the lack of resource materials, hostile attitude of supervisors, the lack of will power on the side of the students, the lack of finance, and ill health among others. Some of these challenges are very high, with the result that many of the postgraduate students of agricultural education have been frustrated out the programme without getting their intended degree certificates after passing their course works creditably. In any case, there were still many postgraduate students of agricultural education who adopted effective coping strategies in overcoming the challenges encountered in thesis writing to be able to obtain their intended postgraduate degree certificate.

Coping, in the explanation of [13], is an effort to manage and overcome demands and critical events that pose a challenge, threat, harm, loss, or benefit to a person. It includes self-regulated goal attainment strategies and personal growth. Reference [14] described coping as an expending conscious effort to solve personal and interpersonal problems, and seeking to master, minimize or tolerate stress or conflict. Psychological coping mechanisms are commonly termed coping strategies or coping skills. Reference [15] viewed coping as the thoughts and actions one used to deal with stress. It can occur as a response to an event or in anticipation of upcoming demands, but it can equally involve a proactive approach to self-imposed goals and challenges. Coping, in the context of this study, is the reaction and effort needed by postgraduate students of agricultural education to minimize or tolerate challenges in thesis writing to obtain their intended postgraduate degree certificate. Weiten in [16] listed three broad types of coping strategies as appraisal-focused, problem-focused and emotion-focused. Typically, people use a mixture of all the three types of coping strategies, and coping skills usually change over time. According to the author, all these methods can prove useful, but some claim that those individuals who use problem-focused coping strategies adjust better to life. It was observed that most successful postgraduate students of agricultural education engaged in thesis writing combined the three types of coping strategies.

However, the researchers were of the opinion that if the challenges encountered by the postgraduate students of agricultural education in thesis writing are identified with coping strategies, the postgraduate students who had or intend to abandon their thesis writing could use them to make necessary adjustment while present and prospective students could adopt some of the coping strategies to overcome challenges in thesis writing. Therefore, the concern of the researchers in this study was to X-ray the challenges encountered by postgraduate students of agricultural education in thesis writing and the coping strategies that could be adopted for success.

\section{Statement of Problem}

It was observed by the researchers that some of their classmates in masters' and Ph.D programme in agricultural education in University of Nigeria, Nsukka, could not continue with their thesis writing to obtain their intended certificate, even when they had passed their course works creditably. On home visitations and telephone calls by the researchers to some of the postgraduate students in agricultural education, the students enumerated series of challenges that frustrated their thesis writing among which poor coping strategies ranked first. A pilot study conducted by the researchers in one other university offering postgraduate programmes in agricultural education equally revealed that a certain percentage of postgraduate students had dropped from their schools at the stage of thesis writing.

However, the pains of starting a programme willingly, paying school fees, finishing course works and aban- 
doning the programme at the stage of thesis writing without a serious health challenge gave the researchers serious concern to identify the challenges faced by postgraduate students of agricultural education in Nigerian universities and the effective copping strategies adopted by other postgraduate students who are successfully advancing in their thesis writing. The view of the researchers was that the result of this study could expose the effective copping strategies of the strong to the weak for adoption to enable them complete their programme successfully.

\section{Research Questions}

1) What are the challenges encountered by postgraduate students of agricultural education in thesis writing?

2) What are the coping strategies adopted by postgraduate students of agricultural education in thesis writing?

\section{Research Hypotheses}

There is no significant difference in the mean ratings of the responses of postgraduate diploma students, master's students and Ph.D students of agricultural education on:

1) challenges encountered by postgraduate students of agricultural education in thesis writing.

2) coping strategies adopted by postgraduate students of agricultural education in thesis writing.

\section{Method}

Two research questions and two hypotheses guided the study. Descriptive survey research design was adopted for this study. Reference [17] stated that a survey research design is a design in which a group of people or items are studied by collecting and analyzing data from a few people or items considered to be the representative sample. Data could be collected using either observation or checklist or interview schedule, or questionnaire. Questionnaire was found appropriate for the study.

The study was conducted in Nigerian universities offering postgraduate programme in agricultural education. The population for the study was 118 made up of 14 postgraduate diploma, 66 masters and 38 doctoral students in agricultural education. This population included current postgraduate students who are at the stage of thesis writing and those who have abandoned their thesis writing for more than three years now. The entire population was involved in the study due to its manageable size, hence there was no sampling. An instrument tilted: Challenges and Coping Strategies Questionnaire (CCSQ) was developed from literature reviewed and experience of the researchers and used for data collection. The questionnaire had a four-point response scale options of highly accepted (HA), averagely accepted (AA), slightly accepted (SA) and not accepted (NA) with a corresponding value of 4, 3, 2 and 1 respectively. Three experts validated the questionnaire items; one from the department of Vocational Teacher Education (Agricultural Education Unit), University of Nigeria, Nsukka, one from Department of Agricultural Education, Delta State University, Abraka and one from Department of Agricultural Education, University of Agriculture, Makurdi. Their corrections and suggestions were used to produce the final draft of the questionnaire. Cronbch alpha reliability method was used to determine the internal consistency of the questionnaire items. A reliability coefficient of 0.85 was obtained. Six research assistants who were familiar with the area of the study were hired and given orientation on how to administer the questionnaire to the supervisors. In addition, [18]'s suggestions for constructing survey instruments, cover letters and follow-up strategies were adopted. A survey with cover letter was sent to some of the postgraduates students (postgraduate diploma, masters' and Ph.D) in the area of the study through mail while some were online. After two weeks, a follow-up letter was sent to remind those who delayed responding to the questionnaire that their cooperation was essential. A total of 110 copies of the questionnaire were returned representing 93 percent return rate. Data collected for the study were analyzed using mean and standard deviation to answer the research questions while Analysis of Variance was used to test hypothesis of no significant difference at $\mathrm{P} \leq 0.05$ level of significance. The statistical package for social sciences (SPSS) was the tool employed to analyze the data collected.

A mean of 2.50 was used for decision-making. Any item with a mean rating of 2.50 or above was regarded as accepted. Also, any item with a standard deviation of 1.96 or below revealed that the respondents were close to the mean and not too far from one another in their responses. The hypothesis of no significant difference was upheld for any item whose P-value was greater than $\mathrm{P} \leq 0.05$ level of significance, while it was rejected for any item whose $\mathrm{P}$-value was less than $\mathrm{P} \leq 0.05$ level of significance. 


\section{Results}

The results of the study were obtained from the research questions answered and hypotheses tested. The results of the study are presented in the Table 1.

Table 1 revealed that 2 out of 28 items had their mean scores as 2.31 and 2.22 and were within the real limit described as not accepted. This indicated that the postgraduate students of agricultural education denied that the 2 items were challenges encountered by them in thesis writing. Eleven (11) out of 28 items had their mean scores ranged from 2.58 to 3.44 and were within the real limit described as averagely accepted. This indicated that the postgraduate students of agricultural education accepted that the 11 items were challenges averagely encountered by them in thesis writing. The table also revealed that 15 out of 28 items and grand mean had their mean scores ranged from 3.51 - 3.93 and were within the real limit described as highly accepted. This indicated that the postgraduate students of agricultural education accepted that the 15 items were challenges highly encountered by them in thesis writing.

Generally, the overall mean of the responses is 3.44 which is within the range of averagely accepted. This indicated that the postgraduate students of agricultural education accepted that all the items were challenges averagely encountered by them in thesis writing. The standard deviation ranged from 0.25 to 1.00 , indicating that the respondents were close to the mean and each other in their responses.

The data on hypothesis tested in Table 1 revealed that all the 28 items had their P-values ranged from 0.11 to 1.13 which were greater than the P-value of 0.05 . This indicated that there was no significant difference in the Analysis of Variance scores of the three groups of respondents (postgraduate diploma, master's and doctoral students) on the challenges encountered in thesis writing. Therefore, the null hypothesis of no significant difference was upheld for the 28 items.

Table 2 revealed that 1 item had its mean score as 2.32 and was within the real limit described as not accepted. This indicated that the item was not a coping strategy adopted by postgraduate students of agricultural education in thesis writing. Three (3) items had their mean score ranged from 2.59 to 3.47 and were within the real limit described as averagely accepted. This indicated that the all the 3 items were the coping strategies averagely adopted by postgraduate students of agricultural education in thesis writing. The table also revealed that 11 items had their mean score ranged from 2.50 to 3.95 and were within the real limit described as highly accepted. This indicated that the all the 11 items were the coping strategies highly adopted by postgraduate students of agricultural education in thesis writing.

Generally, the overall mean of the responses is 3.57 which is within the range of high acceptance. This indicated that the all the items were the coping strategies highly adopted by postgraduate students of agricultural education in thesis writing. The standard deviation ranged from 0.12 to 0.84 , indicating that the respondents were close to the mean and each other in their responses.

The data on hypothesis tested in Table 2 revealed that all the 15 items had their P-values ranged from 0.19 to 1.01 which were greater than the P-value of 0.05 . This indicated that there was no significant difference in the Analysis of Variance scores of the three groups of respondents (postgraduate diploma, master's and doctoral students) on the coping strategies adopted by postgraduate students of agricultural education in thesis writing. Therefore, the hypothesis of no significant difference was not rejected for the 15 items.

\section{Discussion of Findings}

The findings showed that 28 challenges were encountered and 15 coping strategies were adopted by postgraduate students of agricultural education in thesis writing in Nigerian universities. The finding of the study is in line with that of [19] in a study on challenges and prospects of supervision of Adult Education learning centres in Anambra State, Nigeria, in the 21st century, where it was found out that four major challenges affect supervision of Adult Education learning centres in Anambra State. The challenges include the current location of adult education learning centres makes inaccessible for effective supervision, poor funding in the supervision process, non uniformity of supervision process by local, state and federal government and inadequate supervision ration among the three ties of government. Reference [19] also found out that the prospects for effective supervision of adult learning centers include supervision should be done on a regular bases, supervisors should be trained adequately to be competent for the task ahead of them among others. The findings of the study are in agreement with that of [20] on challenges of entrepreneurship as perceived by undergraduate of tertiary institution in Kaduna State, where it was found out that 12 entrepreneurship challenges were faced by undergraduate of tertiary 
Table 1. Mean rating and analysis of variance of the responses of postgraduate diploma, master's and doctoral students of agricultural education on challenges they experience in thesis writing $(\mathrm{N}=110)$.

\begin{tabular}{|c|c|c|c|c|c|}
\hline $\mathbf{S} / \mathbf{N}$ & Item statement on challenges & $\overline{\mathbf{X}}$ & SD & P-value & Remarks \\
\hline 1 & Inability to select a researchable topic for my thesis writing. & 3.93 & 0.60 & 0.12 & Highly accepted ${ }^{*}$ \\
\hline 2 & $\begin{array}{l}\text { There was a disagreement between my supervisors before } \\
\text { approving the topic and as writing progresses. }\end{array}$ & 3.40 & 0.39 & 0.29 & Averagely accepted* \\
\hline 3 & $\begin{array}{l}\text { Inability to understand and cope with the relationship of } \\
\text { concepts in the topic approved for me. }\end{array}$ & 3.87 & 0.42 & 1.13 & Highly accepted ${ }^{*}$ \\
\hline 4 & $\begin{array}{l}\text { Inability to source relevant materials to my research topic } \\
\text { from analogue library. }\end{array}$ & 3.77 & 0.63 & 0.31 & Highly accepted ${ }^{*}$ \\
\hline 5 & $\begin{array}{l}\text { Inability to cope with other academic assignments from my } \\
\text { supervisor(s) outside my course works or thesis. }\end{array}$ & 3.34 & 0.37 & 0.16 & Averagely accepted" \\
\hline 6 & $\begin{array}{l}\text { Developing interest in the topic that my supervisor(s) } \\
\text { approved for me. }\end{array}$ & 3.41 & 0.38 & 0.54 & Averagely accepted \\
\hline 7 & $\begin{array}{l}\text { Inadequate fund to meet with the financial demand of thesis } \\
\text { writing. }\end{array}$ & 3.91 & 0.94 & 0.11 & Highly accepted ${ }^{*}$ \\
\hline 8 & $\begin{array}{l}\text { The topic approved for me is complex and has scanty } \\
\text { literature. }\end{array}$ & 3.27 & 0.27 & 0.63 & Averagely accepted \\
\hline 9 & $\begin{array}{l}\text { My supervisor(s)' poor knowledge of my topic to guide me } \\
\text { properly. }\end{array}$ & 3.51 & 0.56 & 0.50 & Highly accepted ${ }^{*}$ \\
\hline 10 & $\begin{array}{l}\text { My supervisor hardly makes out time to read and guide me in } \\
\text { the thesis writing. }\end{array}$ & 3.63 & 0.29 & 0.47 & Highly accepted ${ }^{*}$ \\
\hline 11 & $\begin{array}{l}\text { I am not computer literate to access digital libraries } \\
\text { (Internet). }\end{array}$ & 2.58 & 1.00 & 0.49 & Averagely accepted \\
\hline 12 & $\begin{array}{l}\text { I have no school library card or password to access analog or } \\
\text { digital library. }\end{array}$ & 3.52 & 0.36 & 0.20 & Highly accepted ${ }^{*}$ \\
\hline 13 & $\begin{array}{l}\text { Series of school internet fluctuation or change of internet } \\
\text { accessing password. }\end{array}$ & 3.73 & 0.37 & 0.30 & Highly accepted ${ }^{*}$ \\
\hline 14 & $\begin{array}{l}\text { My supervisor asked me to write and submit to him/her } \\
\text { without any guide or materials. }\end{array}$ & 3.86 & 0.91 & 0.51 & Highly accepted ${ }^{*}$ \\
\hline 15 & $\begin{array}{l}\text { Late modifications of my topic by my supervisor, proposal or } \\
\text { seminar committee. }\end{array}$ & 3.66 & 0.90 & 0.86 & Highly accepted* \\
\hline 16 & $\begin{array}{l}\text { Nature of job or tight schedule in my place of work tied me } \\
\text { down. }\end{array}$ & 3.83 & 0.63 & 0.28 & Highly accepted ${ }^{*}$ \\
\hline 17 & Family responsibilities held me down. & 3.29 & 0.81 & 0.38 & Averagely accepted" \\
\hline 18 & $\begin{array}{l}\text { Bitter politics among supervisors or readers during } \\
\text { proposal/seminar frustrated me. }\end{array}$ & 3.80 & 0.64 & 0.42 & Highly accepted ${ }^{*}$ \\
\hline 19 & $\begin{array}{l}\text { Respondents demand money to respond to my instrument for } \\
\text { data collection. }\end{array}$ & 3.44 & 0.33 & 0.80 & Averagely accepted \\
\hline 20 & $\begin{array}{l}\text { Collecting certification from my reader(s) to continue was } \\
\text { difficult. }\end{array}$ & 3.13 & 0.25 & 0.73 & Averagely accepted \\
\hline 21 & $\begin{array}{l}\text { Therewas demand for cash or materials from my supervisor } \\
\text { before given due attention to my work. }\end{array}$ & 2.31 & 0.50 & 0.22 & Not accepted ${ }^{*}$ \\
\hline 22 & Sexual harassment from my supervisor. & 3.30 & 0.19 & 0.39 & Averagely accepted \\
\hline 23 & $\begin{array}{l}\text { Distance between my supervisor and I hindered regular } \\
\text { contact. }\end{array}$ & 3.67 & 0.72 & 1.03 & Highly accepted ${ }^{*}$ \\
\hline 24 & $\begin{array}{l}\text { Excessive social, political, religious and marital engagements } \\
\text { left me no time for my thesis writing. }\end{array}$ & 3.51 & 0.83 & 0.21 & Highly accepted ${ }^{*}$ \\
\hline 25 & $\begin{array}{l}\text { My programme sponsorship was withdrawn due to prolonged } \\
\text { delay of my thesis writing. }\end{array}$ & 3.44 & 0.27 & 0.26 & Averagely accepted \\
\hline 26 & My target respondents denied me access for data collection. & 3.21 & 0.18 & 0.24 & Averagely accepted \\
\hline 27 & Natural phenomena interfered with my research work. & 3.71 & 0.34 & 0.18 & Highly accepted ${ }^{*}$ \\
\hline \multirow[t]{2}{*}{28} & $\begin{array}{l}\text { I suspected hindrance to my thesis writing from the spiritual } \\
\text { realm. }\end{array}$ & 2.22 & 0.17 & 0.23 & Not accepted ${ }^{*}$ \\
\hline & Grand mean & 3.44 & 0.51 & 0.43 & Averagely accepted* \\
\hline
\end{tabular}

$\overline{\mathbf{X}}=$ mean, SD $=$ standard deviation, highly accepted $=3.50-4.00$, averagely accepted $=2.50-3.49$, slightly accepted $=1.50-2.49$, not accepted $=$ $1.00-1.49$. 
Table 2. Mean rating and analysis of variance of the responses of postgraduate diploma, master's and doctoral students of agricultural education on coping strategies adopted in thesis writing $(\mathrm{N}=110)$.

\begin{tabular}{|c|c|c|c|c|c|}
\hline $\mathbf{S} / \mathbf{N}$ & Item statement on challenges & $\overline{\mathbf{X}}$ & SD & P-value & Remarks \\
\hline 1 & $\begin{array}{l}\text { I sought help from other competent lecturers and students other } \\
\text { than my supervisors from topic selection to the end of thesis } \\
\text { writing. }\end{array}$ & 3.95 & 0.13 & 0.32 & Highly accepted ${ }^{*}$ \\
\hline 2 & I sourced materials for my thesis with the help of classmates. & 3.86 & 0.33 & 0.93 & Highly accepted ${ }^{*}$ \\
\hline 3 & $\begin{array}{l}\text { I borrowed money to cope with financial challenges to complete } \\
\text { my thesis writing. }\end{array}$ & 3.89 & 0.12 & 1.01 & Highly accepted ${ }^{*}$ \\
\hline 4 & $\begin{array}{l}\text { I sourced materials from cyber café and library with the help of } \\
\text { cyber and library attendants. }\end{array}$ & 3.88 & 0.20 & 0.31 & Highly accepted ${ }^{*}$ \\
\hline 5 & I had to learn computer operation for browsing and data analysis. & 3.74 & 0.15 & 0.27 & Highly accepted ${ }^{*}$ \\
\hline 6 & I published research papers to attract attention from my supervisor. & 2.59 & 0.31 & 0.54 & Averagely accepted" \\
\hline 7 & $\begin{array}{l}\text { I consistently visited my supervisors' office without invitation to } \\
\text { check for my thesis. }\end{array}$ & 3.91 & 0.13 & 0.61 & Highly accepted ${ }^{*}$ \\
\hline 8 & I collected data from respondents with the help of classmates. & 3.87 & 0.17 & 0.19 & Highly accepted ${ }^{*}$ \\
\hline 9 & $\begin{array}{l}\text { I sent my thesis to my supervisor and received corrections from } \\
\text { him via e-mail. }\end{array}$ & 3.47 & 0.62 & 0.23 & Averagely accepted* \\
\hline 10 & $\begin{array}{l}\text { I arranged with or paid my colleagues to perform some official } \\
\text { duties for me to enable me have time for my thesis writing. }\end{array}$ & 3.33 & 0.73 & 0.41 & Averagely accepted ${ }^{*}$ \\
\hline 11 & $\begin{array}{l}\text { My supervisor supervised part of my thesis writing through } \\
\text { telephone calls. }\end{array}$ & 3.76 & 0.47 & 0.26 & Highly accepted ${ }^{*}$ \\
\hline 12 & $\begin{array}{l}\text { I showed cash or material appreciation to my supervisor } \\
\text { periodically. }\end{array}$ & 3.50 & 0.48 & 0.64 & Highly accepted ${ }^{*}$ \\
\hline 13 & I hired research assistance to facilitate my thesis writing. & 3.64 & 0.84 & 0.21 & Highly accepted ${ }^{*}$ \\
\hline 14 & I appreciated my respondents materially to ease data collection. & 3.88 & 0.28 & 0.73 & Highly accepted ${ }^{*}$ \\
\hline \multirow[t]{2}{*}{15} & $\begin{array}{l}\text { I petitioned my supervisor's style of supervision to the appropriate } \\
\text { quarters. }\end{array}$ & 2.32 & 0.16 & 0.70 & Not accepted ${ }^{*}$ \\
\hline & Grand mean & 3.57 & 0.25 & 0.49 & Highly accepted ${ }^{*}$ \\
\hline
\end{tabular}

$\overline{\mathbf{X}}=$ mean, SD $=$ standard deviation, highly accepted $=3.50-4.00$, averagely accepted $=2.50-3.49$, slightly accepted $=1.50-2.49$, not accepted $=$ $1.00-1.49$.

institution. The entrepreneurship challenges include lack of capital, poor government support, lack of skills, poor knowledge based economy among others.

The findings of this study are in line with knowledge that nothing good comes so ease. It also shows that there must be a way out for every challenge that one encounters at any point in time in any situation. Therefore, the postgraduate students of agricultural education who experience challenges and are psychologically weighed down are encourage to adopt some of the identified coping strategies for the sake of making breakthrough in their thesis writing.

\section{Conclusions and Recommendation}

The researchers had the experience that some of their classmates abandoned their postgraduate programme in agricultural education due to frustration and acute delay in their theses writing. The researchers became concerned on why some postgraduate students could not complete their thesis writing when they had finished their course work while some were able to complete theirs and obtained their intended postgraduate degree certificate from the same school, department and supervisors. The study was therefore carried out to identify challenges encountered and coping strategies adopted by postgraduate students of agricultural education in writing thesis in Nigerian universities. It was found out that 28 challenges were encountered by postgraduate students of agricultural education in thesis writing and 15 coping strategies were adopted by postgraduate students of agricultural education in thesis writing. Based on the findings of the study, it is recommended that:

1) Postgraduate students of agricultural education who have abandoned their thesis writing should adopt the identified coping strategies to complete their programme. 
2) Postgraduate students should learn how to help their classmates in their thesis writing.

3) Lecturers of agricultural education should desist from contributing to postgraduate students' frustration and abandonment of their thesis writing.

\section{References}

[1] Barrick, R.K. (1989) Agricultural Education: Building upon Our Roots. Journal of Agricultural Education, 30, $24-29$. http://dx.doi.org/10.5032/jae.1989.04024

[2] Phipps, O., Dyer, B., Lloyd, E. and James, A. (2008) Handbook on Agricultural Education in Public Schools. 6th Edition, Delmar Learning, NY.

[3] Ukonze, J.A. and Olaitan, S.O. (2009) Job-Task Required by Secondary School Graduates for Employment in Rubber Plantation Management Enterprise. Delta State University Journal of Educational Research and Development, 8, 69-87.

[4] Williams, D.L. (1991) Focusing Agricultural Education Research: Strategies for the Discipline. Journal of Agricultural Education, 32, 7-12. http://dx.doi.org/10.5032/jae.1991.01007

[5] Verger, J. (1999) Doctor, Doctoratus. Lexikon des Mittelalters 3. J.B. Metzler, Stuttgart.

[6] Jonhu, B. (2007) Concept of Postgraduate Students. http://www.faceboob.com

[7] Collin, S. (2012) Collings Cobuild English Dictionary for Advanced Learners. 4th Edition, Harper Collins Publishers, New York.

[8] Mauch, J.E. and Park, N. (2003) Guide to the Successful Thesis and Dissertation. University of California-Berkeley, Dissertation Proposal Workshop. http://globetrotter.berkeley.edu/DissPropWorkshop

[9] Thomas, G. (2009) Your Research Project. Sage, Thousand Oaks.

[10] James, E.A. and Slater, T. (2013) A Map for Writing Your Dissertation: Proven Methods for Finishing Faster. Sage Publications, Thousand Oaks.

[11] Pearson, L. (2005) How to Examine a Thesis. McGraw-Hill International, New York, 79-85.

[12] Olaitan, S.O., Ukonze, J.U. and Ifeanyieze, F.O. (2009) Troublesome Areas in Research to Beginners: A Case of Generating a Research Topic. Journal of Nigerian Vocational Association, 14, 161-169.

[13] Lazarus, R.S. and Folkman, S. (1984) Stress, Appraisal, and Coping. Springer, New York.

[14] Lazarus, R.S. (1991) Emotion and Adaptation. Oxford University Press, New York.

[15] Zeidner, M. and Endler, N.S. (1996) Handbook of Coping: Theory, Research, Applications. John Wiley, New York.

[16] Snyder, C.R. (1999) Coping: The Psychology of What Works. Oxford University Press, New York.

[17] Nworgu, B.G. (2006) Educational Research; Basic Issues and Methodology. Windon Publishers Ltd., Ibadan.

[18] Dillman, D.A. (2000) Mail and Internet Survey: The Tailored Design Method. John Wiley and Sons, New York.

[19] Nwobi, A.U. (2011) Challenges and Prospects of Supervision of Adult Education Learning Centers in Anambra State, Nigeria, in 21st Century. Chapter 28. In: Ezeudu, S.A., Ezeani, E.O., Onuoha, J.O. and Nwizu, S.C., Eds., Nigeria at Fifty: Issues, Challenges and Agenda, Vol. 1, Timex Publisher, Enugu, 316-327.

[20] Mustapha, A.I., Yunusa, U. and Pelemo, I.F. (2013) Challenges of Entrepreneurship as Perceived by Undergraduate of Tertiary Institution in Kaduna State. In: Onyegegbu, N. and Eze, U., Eds., National Transformation through Entrepreneurial Education, Timex Publisher, Enugu, 196-209. 
Scientific Research Publishing (SCIRP) is one of the largest Open Access journal publishers. It is currently publishing more than 200 open access, online, peer-reviewed journals covering a wide range of academic disciplines. SCIRP serves the worldwide academic communities and contributes to the progress and application of science with its publication.

Other selected journals from SCIRP are listed as below. Submit your manuscript to us via either submit@scirp.org or Online Submission Portal.
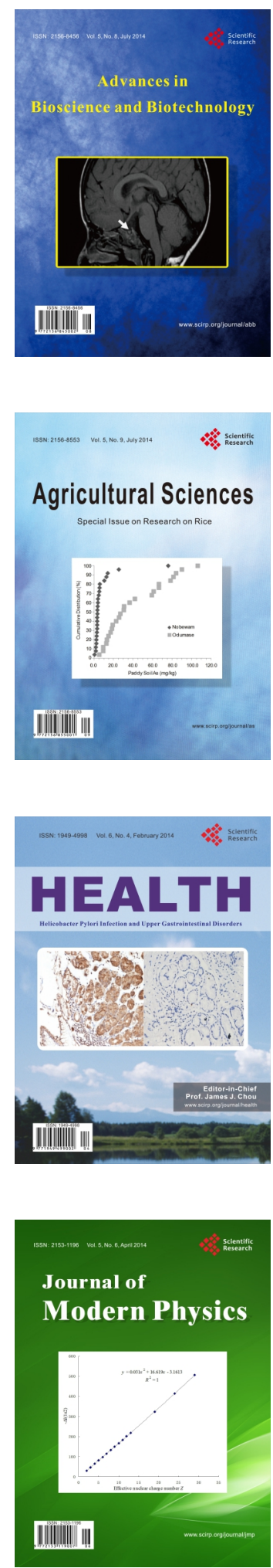
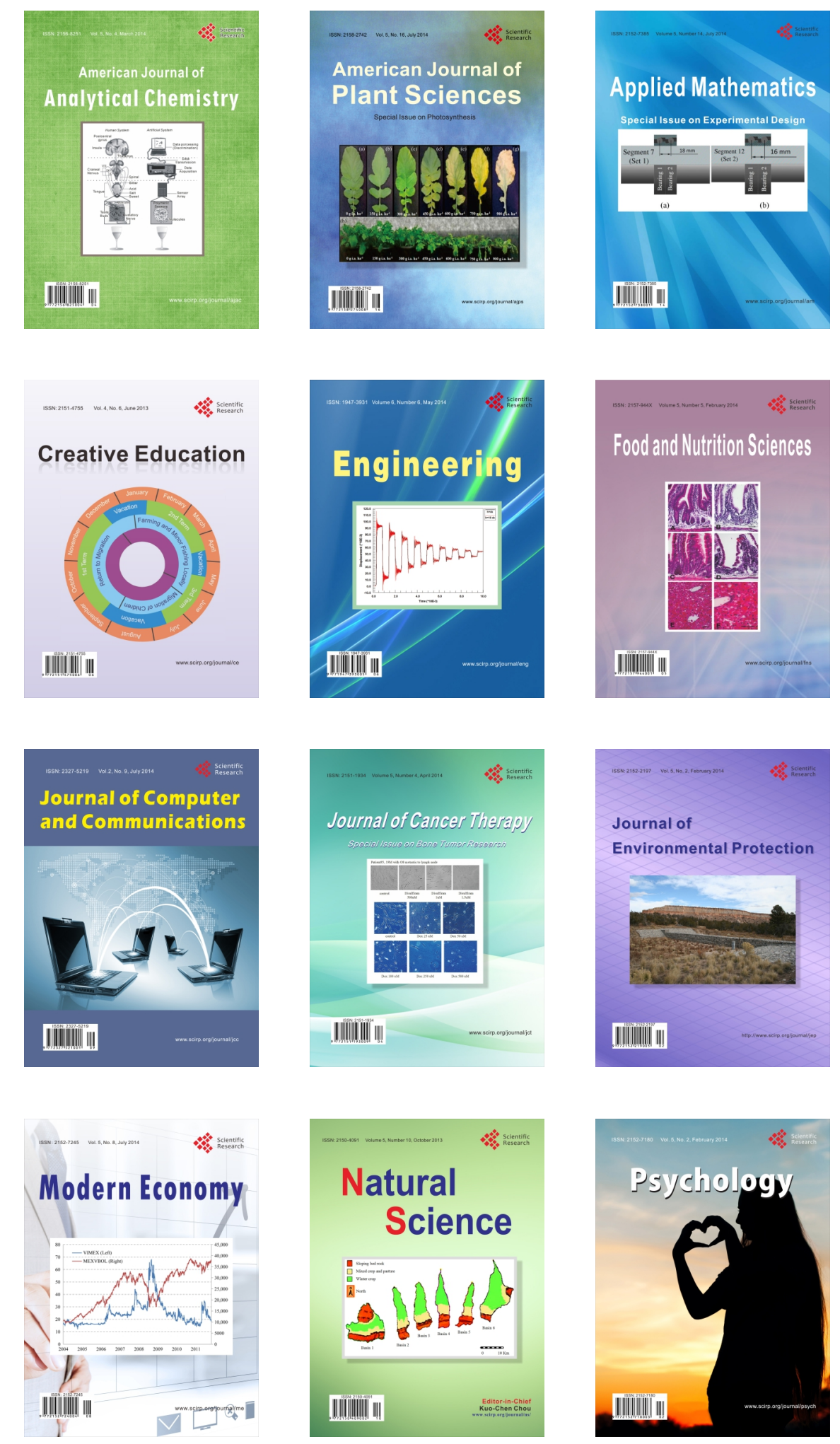